\title{
THE DEVELOMENT OF INTERACTIVE BLENDED PROBLEM BASED LEARNING MODEL FOR PROGRAMMING SUBJECT
}

\author{
Hansi Effendi ${ }^{1}$, Yeka Hendriyani ${ }^{2}$ \\ ${ }^{1}$ Faculty of Engineering, Universitas Negeri Padang, Indonesia; ${ }^{2}$ Universitas Negeri Padang, Indonesia
}

\begin{abstract}
This article discusses the results of research on conceptual model and hypothetical model development of Interactive Blended Problem Based Learning (IBPBL) in Programming Language subject for Electrical Engineering students of Universitas Negeri Padang. The model is a blended learning model which mix between face-to-face learning in the classroom and moodle-based online learning with problem-based learning syntax in the field of Electrical Engineering. The study was conducted in three stages: (1) literature review, (2) conceptual model formulation, and (3) hypothetical model formulation. The IBPBL conceptual model includes: (1) a philosophical component: pragmatism; (2) theoretical components: cognitivism, behaviorism, constructivism, and connectivism; (3) methodological components: problem-based learning; and (4) technical components: problem solving, collaboration, critical thinking, innovative, creative, and systematic. While the hypothetical model is based on the ability of students in solving problems critically, creatively, collaboratively, systematically by utilizing various advantages possessed by face-to-face and online learning in programming language course in Electrical Engineering.
\end{abstract}

\section{Keywords: Instructional Model Development, Blended Learning, Problem Based, Interactive, Programming}

\section{INTRODUCTION}

Programming Language Course is a basic course that is very important in supporting other subjects. If students have good competence in this course, this skill can be used to solve the existing engineering problem using computer. Almost all majors in the Faculty of Engineering have this course although with a different name. This course should be taught with the same competence as examples of applications in accordance with their respective majors.

From the preliminary survey it is known that in some departments, this course is taught in the final semester, whereas this course is the supporting course for other courses that require computer in solving the problem. There are also those who teach this course in general and without any relation to the problems that exist in the field so that students are not aware that the competence it has in programming language is a powerful tool in solving various engineering problems.

Many learning models are developing, but certainly not all existing models are suitable for all subjects. In theory no single learning model is suitable for all learning models. So the learning model should be developed in accordance with the needs and characteristics of the course. One of the learning methods that match the character of the programming language course that the purpose of solving various engineering problems is Problem Based Learning (PBL).

PBL is a method of learning and training, characterized by real-world problems as a context for learners to learn critical thinking and problem-solving skills and gain knowledge. The typical characteristic of PBL that differentiates it from other learning methods is where the PBL centers on what the learners do, not what the lecturers do [1]. Therefore PBL is closer to the Student Centered Learning approach. PBL can be applied in individual and group learning processes. This method can also be applied in the classroom setting and other types of learning, such as online learning [2].

In the context of distance learning, PBL applications are also applied in online or network learning, both intranet and internet. PBL provides an opportunity for learners to solve problems according to individual ways or learning styles (visual, audio, kinesthetic).

Blended learning or hybrid courses is a learning that combines online components and face-to-face components. Furthermore, it also describes all learning programs that incorporate various learning media or learning opportunities. At the most basic level, they involve thinking, reading and mixing new information with existing knowledge.

Blended learning model with problem based approach must provide various basic idea form on each material to be presented. The existence of material that provides a known facts presentation and provides opportunities for learners to learn various issues which then proceed with implementing problem-solving action. Furthermore, the design of blended learning model created to directly provide opportunities for the evaluation.

The Interactive Blended Problem Based Learning (IBPBL) model is a constructivist learning model which is a mixture of face-to-face learning in the classroom with online learning using Moodle-based e-learning which is an e-learning platform that 
already existed at Universitas Negeri Padang. Some of the characteristics of this model are: (a) the learning process is student centered, (b) the learning process takes place in small groups, (c) the teacher acts as facilitator or mentor, (d) the problems presented in the learning are organized in the form and the particular focus is a learning stimulus, (e) new information is gained through self-directed learning, and (f) problems are the means to develop problemsolving skills [3].

The IBPBL model was developed from the previous model of the Web-Based Interactive Blended Learning (WBIBL) model which was also developed for the programming language course. One of the drawbacks of this model is that it has not yet integrated the PBL model, which is identified as the cause of the students being unable to solve problems that require critical, systematic, and innovative thinking skills to solve programming problems [4].

PBL can provide learners with the opportunity to develop critical thinking skills. Learners are trained to develop ways of discovering, questioning, articulating, describing, considering, and decisionmaking. That is, learners apply a work process through a problem situation or situation that contains problems. By implementing PBL learners apply knowledge and skills, not just receive information alone.

\section{RESEARCH METHODOLOGY}

This research was conducted at the Department of Electrical Engineering Faculty of Engineering, Universitas Negeri Padang (UNP). This research is Research \& Development using Borg and Gall approach.

There are 10 steps to take if using the Borg \& Gall model for the development of a model / product, namely: (a) research and information collecting; (b) planning; (c) develop preliminary form of product; (d) preliminary field testing; (e) main product revision; (f) main field testing; (g) operational product revision; (h) operational field testing; (i) final product revision; and (j) dissemination and implementation [5]. The ten step of Borg and Gall procedure is shown by Fig 1 .

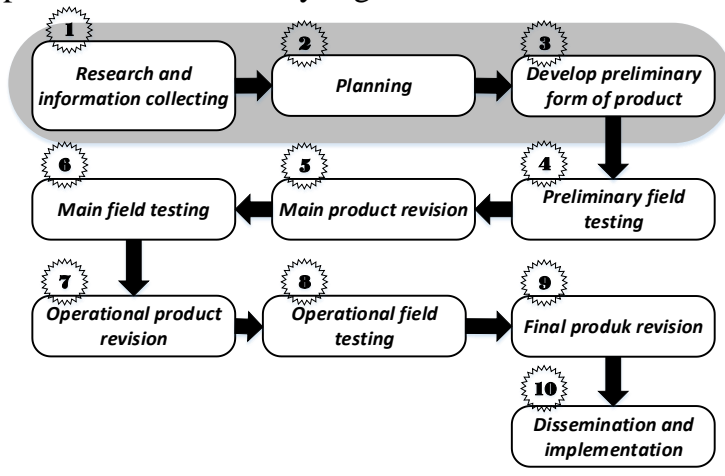

Fig.1 R \& D Procedure of Borg and Gall

\subsection{Research and information collecting}

In this section, literature studies are conducted on: blended learning, problem-based learning, integration of blended learning with problem-based learning, effective blended problem-based learning, relevant research, and needs analysis of blended learning at UNP.

\subsection{Planning}

This section defines product development objectives and indicators or product effectiveness criteria and small-scale feasibility tests. Feasibility test is conducted to see the availability of facilities and infrastructure that exist in UNP related to model development and research implementation.

\subsection{Develop preliminary form of product}

This section is based on literature studies to prepare conceptual models, hypothetical models, instructional materials, and evaluation instruments. Conceptual models include: philosophical foundations, theoretical framework, methodological components, and methodical / technical components. The hypothetical model is a temporary model of the IBPBL model derived from the conceptual model which is the basis for the development of learning syntax.

\section{RESULTS AND DISCUSSIONS}

Based on the three stages of development procedures described above, the discussion in this section is divided into three stages: (a) literature review, (b) conceptual model formulation, and (c) hypothetical model formulation.

\subsection{Literature Review}

Many blended learning models have been developed. Categorization is various. As an example, NIIT categorizes blended learning into three models: (a) skill-driven learning, which combines self-paced learning with instructor or facilitator support to develop specific knowledge and skills; (b) attitudedriven learning, which mixes various events and delivery media to develop specific behaviors; and (c) competency-driven learning, which blends performance support tools with knowledge management resources and mentoring to develop workplace competencies [6].

Meanwhile, Educators have developed 6 models for blended learning, namely: (a) the face-to-face driver model: this model works best for diverse classrooms in which students are functioning at various levels of ability and mastery; (b) the rotation 
model: this is really just a variation of the learning stations model that teachers have been using for years. There is a set schedule by which students have face-to-face time with their teachers and then move to online work; (c) the flex model: this model relies heavily on online instructional delivery, with teachers acting as facilitators rather than as primary deliverers of instruction; (d) the online lab school model: this model involves students traveling to and attending a school with total online educational delivery for entire courses; (e) self-blend model: this model allows coursework beyond that offered in a tradition setting in a specific school or district. Students participate in traditional classes but then enroll in courses to supplement their regular programs of study; and (f) the online driver model: this model is the complete opposite of a traditional face-to-face instructional environment. Students work from remote locations (e.g., their homes) and receive all of their instruction via online platforms. Usually, there are opportunities to "check-in" with a course teacher and to engage in online messaging if an explanation is needed [7].

One that distinguishes the PBL model from other learning models is the syntax. The PBL syntax consists of five stages: (a) introduction, (b) starting a new problem, (c) follow-up problems, (d) presentation performance, and (e) after conclusion of problem. These five stages are shown in detail in Fig 2.

\begin{tabular}{|l|l|}
\hline & \multicolumn{1}{|c|}{ The Syntax of PBL Model } \\
\hline Int & INTRODUCTION \\
\hline & STARTING A NEW PROBLEM \\
& 1. Present a set of issues related to the topic to be studied \\
2. Internalization of problems by students (small groups)
\end{tabular}

Fig.3 The syntax of PBL model [8]
The integration of blended larning with PBL has been done by previous researchers. Among them are research conducted by Donnelly that integrates blended learning with PBL for teacher education [9]. Other researchers include Moeller, Spritzer, and Spreckelsen who tried several interactive component combinations to see the exact blended problem based learning configuration [10].

Based on preliminary study at UNP, it was concluded that the University already has sufficient ICT facilities to implement blended learning, which includes: availability of bandwidth, storage devices, fiber optic network integrated with Telkom and Indosat connecting buildings on the main campus, Moodle as its learning management system, and laboratory computers with sufficient capacity.

\subsection{Conceptual Model Formulation}

Conceptual model consists of four components, namely: (a) a philosophical foundation: pragmatism; (b) theoretical frameworks: cognitivism, behaviorism, constructivism, and connectivism; (c) methodological components: problem-based learning; and (d) technical components: problem solving, collaboration, communication, critical thinking, creative thinking, innovation, and systematic.

\subsubsection{Philosophical foundation}

Miller identifies three main philosophies of vocational education that are also philosophies for education in general: essentialism, existentialism, and pragmatism [11]. Furthermore, Miller defines it as follows.

Essentialism: The educator or trainer is the focal point of the learning process; mastery of subject matter is important; development of skills through drills, repetition, conditioning, and development of desirable habits; a desire to influence the behavior of the learner.

Existentialism: The learner is the focus of the learning process; truth is relative; and personal growth and development are key to the process.

Pragmatism: The educator and learner are both important to the learning process; reality or realworld situations are stressed; context and experience are important; and the educator is progressive, and open to new ideas.

The philosophy foundation used in the IBPBL model is Pragmatism. Pragmatism considers thinking as an instrument or tool for prediction, problem solving and action, and rejects the idea that the function of thought is to describe, represent, or reflect reality. 


\subsubsection{Theoretical framework}

There are four theoretical frameworks used in the development of the IBPBL model: (a) behaviorism paradigm, (b) cognitivism paradigm, (c) constructivism paradigm, and (d) connectivism.

In the behaviorism paradigm, learning is defined as behavioral change that can be facilitated through strengthening specific stimuli and responses [12], and students are considered reactive to conditions in their environment [13]. This may mean that the lecturer encourages student specific behavior outcomes through a set of defined learning objectives [14].

The paradigm of cognitivism focuses on the student's mental activity. Because of its emphasis on mental structure, this theory is considered more appropriate to explain complex forms of learning, such as: reasoning, problem solving, and information processing. In cognitive learning, knowledge acquisition is described as a mental activity that requires coding and internal organization by students so that students are considered as an active participant in the learning process [13]. This paradigm believes that learning is the result of organizing and processing information effectively [15], therefore information should be organized so that learners can connect new information with existing information in meaningful ways [13].

Constructivism puts learners in an open learning environment where they build their own meaning from knowledge and content. Environmental factors are considered important because the synergy between students and the environment creates knowledge. In constructivist learning, it is important to learn to occur in realistic settings and the learning task must be relevant to the learner [13]. So the constructivist learning environment must provide a rich experience that encourages students to learn. The goal is to teach a great concept by using student activity, social interaction, and authentic assessment [16].

Connectivism was introduced by George Siemens which is a theory of learning in the digital age. This theory aims to provide insight into learning skills and tasks required in the digital age. This theory argues that learning is no longer an internal, individualistic activity and that the way people work and function is changed when new tools are exploited [17]. This approach emphasizes the importance of information and connects it to the right people, so efficient navigation and information filtering is essential.

\subsubsection{Methodological components}

The methodological component that is used in IBPBL model is problem based learning. Problembased learning is designed in a learning procedure that begins with a problem and uses the instructor as a metacognitive trainer. The learning process begins once students are exposed to the real problem structure, so they know why they should study the material. After that they must gather information to be analyzed and use that information in solving the problems encountered.

Through problem-based learning, students learn how to use interactive processes to evaluate what they know, identify what they need to know, gather information, and collaborate in evaluating a hypothesis based on data collected. While the lecturer acts as tutor and facilitator in digging and finding the hypothesis, and take conclusion.

\subsubsection{Methodical/technical components}

21 st century skills are a set of skills, abilities, and dispositions that have been identified that are needed for success in the 21 st century society and workplace. Many of these skills are related to deeper learning, based on mastering skills such as analytic reasoning, complex problem solving, and teamwork. These skills differ from traditional academic skills because their basic knowledge is not knowledge-based. Some of these skills are: critical thinking, creative thinking, communication, and collaboration.

PBL provides opportunities for learners in the development of critical thinking skills. Learners are trained to develop ways of discovery, questioning, articulating, describing, considering, and decisionmaking. That is, learners apply a work process through a problem situation or situation that contains problems.

The conceptual model of BPBLI that is discusses above is shown in Fig 3.

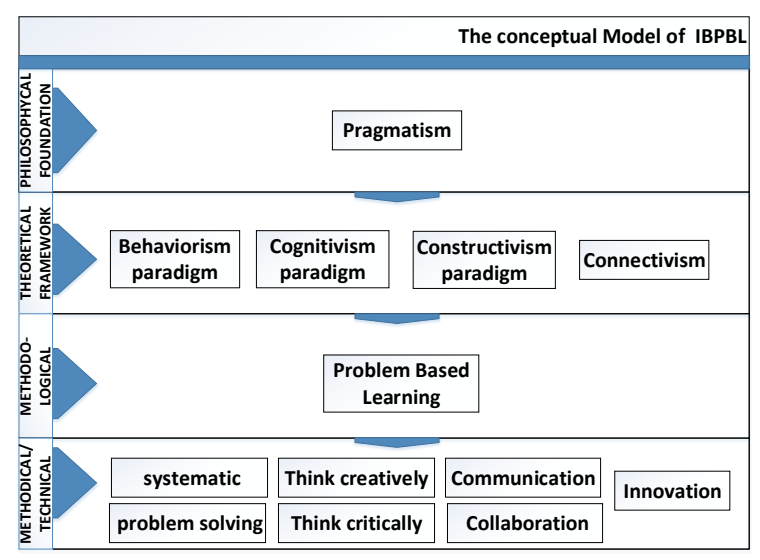

Fig.3 The conceptual model of IBPBL

\subsection{Hypothetical Model Formulation}

The hypothetical model is based on the ability of students in solving problems critically, creatively, collaboratively, systematically by utilizing various advantages possessed by face-to-face and online 
learning in programming language course in Electrical Engineering. The hyphotetichal model of IBPBL is shown in Fig 4.

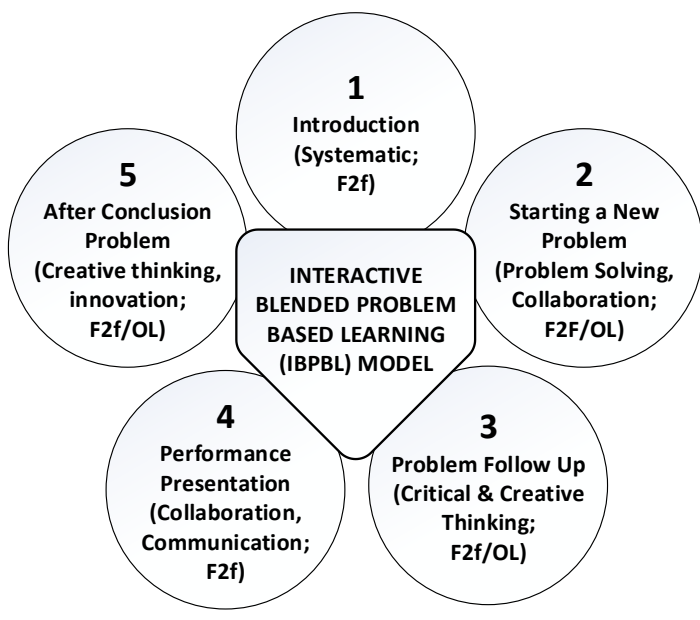

Fig.4 The hypothetical model of IBPBL

\subsection{Discussions}

Lots of blended learning models have been developed, especially in Universitas Negeri Padang. Some of them are Interactive Blended Learning (IBL) model that consider locus control and student learning styles [18]. This model has been tested into several courses and has been proven effective in improving student learning outcomes. Especially for programming subject has also been developed model of Web-Based Interactive Blended Learning (WBIBL) which has also been tested its effectiveness but there are still shortcomings that is not yet developed the ability of students in solving programming problems presented in the form of program code problems [4].

The IBPBL model tries to solve the problem so it is expected that this model can overcome the obstacle in terms of growing soft skill of students especially in solving programming problem. The collaboration between face-to-face learning in the classroom and online learning with syntax of problem-based learning is expected to address this issue. Some other skills that are wanted to grow by learning to use this model are the ability in communication, collaboration, creative thinking, critical thinking, systematic, and innovative. Those skills are necessary for students in solving problems in the course of programming languages.

\section{CONCLUSION}

Based on the literature study, an interactive blended learning model with the syntax of problem based learning has been developed with the name of Interactive Blended Problem Based Learning which is abbreviated as IBPBL with the following model components: (1) a philosophical foundation: pragmatism; (2) theoretical frameworks: cognitivism, behaviorism, constructivism, and connectivism; (3) methodological component: problem-based learning; and (4) methodical / technical components: problem solving, collaboration, critical thinking, innovative, creative, and systematic. The hypothetical model is based on the ability of students in solving problems critically, creatively, collaboratively, systematically by utilizing the advantages possessed by face-to-face and online learning in programming language course in Electrical Engineering.

\section{ACKNOWLEDGEMENTS}

This study would not be conducted well and effective without the supports of several parties. The author will deliver gratefulness to:

a. The Deans of Faculty of Engineering who had given supports that the author was able to conduct research at faculties and study programs.

b. The heads of Electrical Engineering Study Program, who had given permission to their lecturers and students to be the respondents of the study.

c. The lecturers and students who willingly provided any information by completing the questionnaires properly.

\section{REFERENCES}

[1] D. MacDonald \& G. Isaacs, "Developing a professional identity through problem-based learning". Teaching Education, 12(3), 315-333, 2001)

[2] M. Savin-Baden, "The challenge of using problem-based learning online," London: Routledge, Taylor \& Francis Group, 2007.

[3] I. W. Sadia, "Model-model pembelajaran sains konstruktivistik," Yogyakarta: Graha Ilmu, 2014.

[4] H. Effendi and Y. Hendriyani, "The effectiveness of web-based interactive blended learning model in programming language courses.," in Regionalization and Harmonization in TVET: Proceedings of the 4th UPI International Conference on Technical and Vocational Education and Training (TVET 2016), November 15-16, 2016, Bandung, Indonesia, 2017, pp. 175-178.

[5] M. D. Gall, J. P. Gall, and W. R. Borg, "Educational Research: An Introduction," Pearson Education Inc., Boston, 2003.

[6] P. Valiathan, "Blended learning models," American Society for Training and Development, 2010. 
[7] Dreambox, "6 models of blended learning", available in http;//dreambox.com, 2013.

[8] H. S. Barrows, and A. C. Myers, "Problem-based learning in secondary schools," Springfield, IL: Problem-Based Learning Institute, Lanphier High School and Southern Illinois Medical School, 1993.

[9] R. Donnelly , "Blended problem-based learning for teacher education: lesson learnt," Learning, Media, and Technology, 31(2), 93-116, 2007.

[10] S. Moeller, K. Spritzer, and C. Spreckelsen, "How to configure blended problem based learning - results of a randomized trial," Institute for Medical Informatics, Germany, 2010.

[11] M. D. Miller, "Principles and a philosophy for vocational education" Washington D. C.: Ohio State University, 1985.

[12] L. Naismith, P. Lonsdale, G. Vavoula, \& M. Sharples, "Report 11: Literature review in mobile technologies and learning. NESTA Futurelab Series. Available in: http://archive.futurelab.org.uk/resources/docum ents/lit_reviews/Mobile_Review.pdf. Accessed: 13.8.2017, 2005.

[13 ] P. A. Ertmer, \& T. J. Newby, "Behaviorism, Cognitivism, Constructivism: Comparing
Critical Features From an Instructional Design Perspective. Performance Improvement Quarterly, 6(4), 50-72, 1993.

[14] D.C. Leonard, "Learning Theories, A to Z," Westport, Conn: Oryx Press, Available in: eBook Collection (EBSCOhost), Ipswich, MA, 2002.

[15] A. Jordan, A. Stack, \& O. Carlile, "Approaches to Learning : A Guide for Teachers," Maidenhead: Open University Press, 2008.

[16] D. H. Schunk, "Learning theories: an educational perspective. (6th edition) Boston MA ; London: Pearson, 2012.

[17] G. Siemens, " Connectivism: A Learning Theory for the Digital Age," elearnspace everything elearning. Available in:http://www.elearnspace. org/Articles/connectivism.htm, 2004. Accessed: 19.8.2017.

[18] Z. Mawardi Effendi, H. Effendi, and H. Effendi, "The role of locus control and learning styles in the development of the blended learning model at PSU," Int. J. GEOMATE, vol. 13, no. 7, pp. 75-80, 2017. 